Available online on 18.01.2021 at http://jddtonline.info
Oc 2011-21, publisher and licensee JDDT, This is an Open Access article which permits
unrestricted non-commercial use(CC By-NC), provided the original work is properly cited
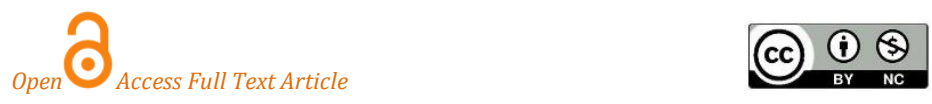

Research Article

\title{
Molecular Characterization of Carbapenemase-Producing Enterobacterales in Children with Diarrhea in Rural Burkina Faso
}

René Dembélé1,2*, Issiaka Soulama ${ }^{3}$, Wendpoulomdé Aimé Désiré Kaboré1, Ali Konaté1^, Assèta Kagambèga ${ }^{1,4}$, David Coulibaly N'Golo5 ${ }^{5}$, Oumar Traoré1,2, Abdoulaye Seck ${ }^{6,7}$, Alfred Sababenedyo Traoré1, Nathalie Guessennd 8,9 , Amy Gassama-Sow ${ }^{10^{\wedge}}$ and Nicolas Barro ${ }^{1}$

${ }^{1}$ Laboratory of Molecular Biology, Epidemiology and Surveillance of Bacteria and Viruses Transmitted by Food/Center for Research in Biological, Food and Nutritional Sciences/Graduate School of Science and Technology/University Joseph KI-ZERBO, 03 BP 7021 Ouagadougou 03, Burkina Faso.

${ }_{2}^{2}$ Training and Research Unit in Applied Sciences and Technologies/University of Dedougou, BP 176 Dedougou, Burkina Faso.

${ }^{3}$ National Centre for Research and Training on Malaria, 01 BP 2208 Ouagadougou 01, Burkina Faso.

${ }^{4}$ Institute of Sciences, 01 BP 1757 Ouagadougou 01, Burkina Faso.

${ }^{5}$ Molecular Biology Platform, Pasteur Institute of Abidjan, Ivory Coast, 01 BP 490 Abidjan 01.

${ }^{6}$ Laboratory of Biological and Medical Analyzes, Pasteur Institute of Dakar, Dakar, Senegal.

7 Faculty of Medicine, Pharmacy and Odontology, University of Cheikh Anta DIOP of Dakar, Senegal.

${ }^{8}$ Laboratory of Bacteriology-Virology, Unit of Antibiotics, Natural Substances and Surveillance of Resistance of Microorganisms to Antimicrobials/ Pasteur Institute of Abidjan, Ivory Coast, 01 BP 490 Abidjan 01.

${ }^{9}$ Laboratory of Bacteriology-Virology/Unit of Training and Research of Medical Sciences/University Felix Houphouet BOIGNY, 01 BP V34 Abidjan 01, Ivory Coast.

${ }^{10}$ Unit of Experimental Bacteriology, Pasteur Institute of Dakar, 36 avenue Pasteur, BP 220, Dakar, Senegal.

Ali Konaté and Amy Gassama-Sow are deceased

\section{Article Info:}

Article History:

Received 04 Nov 2020;

Review Completed 28 Dec 2020

Accepted 06 Jan 2021;

Available online 18 Jan 2021

\section{Cite this article as:}

Dembélé R, Soulama I, Kaboré WAD, Konaté A, Kagambèga A, N'Golo DC, Traoré $\mathrm{O}$, Seck A, Traoré AS, Guessennd N, Gassama-Sow A, Barro N, Molecular Characterization of CarbapenemaseProducing Enterobacterales in Children with Diarrhea in Rural Burkina Faso, Journal of Drug Delivery and Therapeutics. 2021; 11(1):84-92 DOI: http://dx.doi.org/10.22270/jddt.v11i1.4513

*Address for Correspondence:

René Dembélé, Training and Research Unit in Applied Sciences and Technologies/University of Dedougou, BP 176 Dedougou, Burkina Faso. ORCID ID: 0000-0002-9282-8555

\section{Abstract}

Background and objective: In recent years, carbapenemase-producing Enterobacterales (CPE) resistance to antibiotics has dramatically increased leading to limitations of their treatment options. In the present study, we investigated the occurrence of carbapenemase-producing Escherichia coli and Salmonella in rural Burkina Faso.

Materials and methods: Salmonella isolates were serotyped according to the Kauffman White scheme. Diarrheagenic Escherichia coli (DEC) strains was identified using 16-plex Polymerase Chain Reaction (PCR), whereas antibiotic susceptibility was realized using the disk diffusion method. Furthermore, multiplex PCR assays were carried out using oligonucleotides to detect the presence of genes of the $b l a_{\mathrm{KPC}}$, $b l a_{\mathrm{VIM}}, b l a_{\mathrm{IMP}}, b l a_{\mathrm{TEM}}, b l a_{\mathrm{SHV}}, b l a_{\mathrm{OXA}}$ and bla $a_{\mathrm{CTX}-\mathrm{M}}$ types in all E. coli and Salmonella strains.

Results: The study highlighted high resistance rates of the identified bacteria to common antibiotics. Likewise, two strains of $E$. coli were imipenem resistant with carbapenemase-encoding genes. The genes detected were Klebsiella pneumoniae carbapenemase (KPC), Verona integrin-encoded metallo- $\beta$-lactamase (VIM) and Imipenemase (IMP-2) reaching a rate of $40 \%$ each in $E$. coli strains. However, no Salmonella carbapenemases blaKPC, blaVIM or blaIMP were detected.

Conclusion: This study showed that for a real-time infection control and prompt application of antimicrobial chemotherapy, characterization of carbapenemaseproducing Enterobacterales in patients is crucial.

Keywords: Antibiotics, Carbapenemase-Producing Enterobacterales, children, Burkina Faso.

Conflict of Interest: The authors stipulate that they have no conflict of interest in regard to this study. 


\section{INTRODUCTION}

New antimicrobial resistance mechanisms are emerging and spreading globally, hampering our ability to effectively treat common infectious diseases. This has extended illness, disability and increased death rates 1. As a result, antimicrobial resistance represents a major challenge for public health worldwide. One of the most worrying threat is the emergence and rapid dissemination of carbapenem resistant Gram-negative bacteria, following the spread of carbapenemase-producing Enterobacterales (CPE) 2, 3. In bacteria of animal and human origins, beta-lactam resistance, which includes resistance to extended-spectrum beta-lactams, has now been increasingly observed ${ }^{4}$. In Enterobacteriaceae, the carbapenemases have been previously classified into the three following classes : class A [ie K. pneumoniae carbapenemase (KPC) enzymes], Class B [ie metallo-beta-lactamases (MBL)] including New Delhi metallo- $\beta$-lactamase (NDM), Verona integrin-encoded metallo- $\beta$-lactamase (VIM), Imipenemase (IMP), and Class D [ie oxacillinase (OXA)-48 and related variants] 5-7. Enterobacteriaceae can be resistant to carbapenems through intrinsic or acquired mechanisms. The chromosomallyencoded mechanisms can occur by (a) production of chromosomal carbapenemases from the group of class A serine carbapenemases ${ }^{8}$ or (b) efflux pumps or (c) reduction in outer membrane permeability through porin loss ${ }^{9}$. The acquired resistance is a plasmid-mediated mechanism through which the mobile carbapenemases are easily transmitted between bacteria ${ }^{10}$.

The recent spread of CPE is one of the major public health threats worldwide ${ }^{11}$ because carbapenems are among the main stay of therapy for treating severe infections directly related to multidrug-resistant bacteria producing extendedspectrum $\beta$-lactamases (ESBLs) 12. Carbapenemases are defined as $\beta$-lactamases that hydrolyze almost all betalactam antibiotics. According to some recent studies, the most prevalent carbapenemases in Enterobacteriaceae are bla $_{\mathrm{KPC}}\left(\right.$ Ambler class A), blaviM, bla ${ }_{\mathrm{IMP}}$, bla $_{\mathrm{NDM}}$ (class B) and bla $_{0 \mathrm{XA}}-48$ like (class D) 11, 13. Although several studies reported the occurrence of carbapenemases producing bacteria in Africa 12, to our best knowledge, no study focusing on the molecular characterization of Carbapenemase-producing E. coli and Salmonella has been undertaken in Burkina Faso. Therefore, the objective of the present study was to carry out a molecular characterization of carbapenemase-Producing Escherichia coli and Salmonella isolates recovered from children in two rural hospitals in Burkina Faso.

\section{MATERIAL AND METHODS}

\section{Study design and population}

A prospective cross sectional study was conducted to determine the serotypes and antimicrobial susceptibility of diarrheagenic E. coli and Salmonella among children visiting hospitals in rural settings of Burkina Faso.

\section{Settings}

This study was conducted in north (Gourcy, distance 140 $\mathrm{km}$ ) and western (Boromo, distance $185 \mathrm{~km}$ ) of the capital Ouagadougou, Burkina Faso (Fig. 1). The main sources of income in these rural settings are subsistence farming, animal husbandry and small scale trade.

\section{Specimen collection}

Two hundred and seventy five (275) faecal samples were taken in 2009-2010 by trained health staff personnel using a swab transport system (M40 transystemAmies agar gel without charcoal; Copan Italia Spa, Brescia, Italy) and transported to laboratory within $24 \mathrm{~h}$ of their collection for analysis. A questionnaire was used to collect demographic information (e.g., age and sex) of each patient).

\section{Salmonella isolation and serotyping}

Selenite broth (Emapol, Pologne) was used for the enrichment of specimens followed by an incubation at $37^{\circ} \mathrm{C}$ for $18 \mathrm{~h}$. Subsequently, samples were cultured on Hecktoen Enteric agar (Liofilchem, Italy) and incubated at $37^{\circ} \mathrm{C}$ for 24h. The identity of typical-looking Salmonella colonies on Hektoen was examined by using orthonitrophenyl-ß-Dgalactopyranoside (ONPG), citrate, mannitol, lysine decarboxylase tests and the Kliger Hajna medium (Liofilchem, Italy). Finally the isolates were confirmed by API 20E (BioMérieux, Marcy l'Etoile, France). All Salmonella isolates were serotyped by the Salmonella Reference Laboratory. Isolates were serotyped with the somatic 0 and flagellar $\mathrm{H}$ anti-sera according to the Kauffman White scheme ${ }^{14}$.

\section{E. coli isolation and identification}

Stool samples were plated on eosin methylene blue agar (Liofilchem, Italy), and the plates were incubated at $+37^{\circ} \mathrm{C}$ for 18-24 h. After incubation, the suspected colonies were selected and streaked onto Mueller Hinton agar plate (Liofilchem, Italy). Confirmation was carried out by a biochemical microbiology method based on negative urease (Bio-Rad, France), negative citrate (Liofilchem, Italy), positive indole (Bio-Rad, France), positive lactose (Liofi lchem, Italy), and positive orthonitrophenyl- $\beta$-Dgalactopyranoside (ONPG) (bioMerieux, France). E. coli strains isolated were confirmed by API 20E (bioMérieux, France).

The 16-plex PCR was used to detect simultaneously 16 genes from the five main pathogroups of $E$. coli (enterohemoragic E. coli: EHEC, enteropathogenic E. coli: EPEC, enteroaggregative E. coli: EAEC, enteroinvasive E. coli: EIEC and enterotoxigenic E. coli: ETEC) as described by Antikainen et al. ${ }^{15}$. The genes investigated and primers used are listed in Table 15-17.

\section{Antimicrobial susceptibility testing}

Antibiotic susceptibility was determined on Mueller-Hinton agar (Liofilchem, Italy) using the standard disc diffusion procedure as described by the European Committee of Antimicrobial Susceptibility Testing (EUCAST) ${ }^{18}$. Nineteen antibiotics belonging to 7 different families (Table 2) were tested: amoxicillin (25 $\mu \mathrm{g})$, amoxicillin-clavulanic acid $(20 / 10 \mu \mathrm{g})$, ceftriaxone $(30 \mu \mathrm{g})$, cefotaxime $(30 \mu \mathrm{g})$, cefepime $(30 \mu \mathrm{g})$, cefixime $(10 \mu \mathrm{g})$, piperacillin $(75 \mu \mathrm{g})$, piperacillin-tazobactam $(100+10 \mu \mathrm{g})$, imipenem $(10 \mu \mathrm{g})$, tetracycline $(30 \mu \mathrm{g})$, chloramphenicol $(30 \mu \mathrm{g})$, trimethoprimsulfametoxazole $(1.25 \pm 23.75 \mu \mathrm{g})$, aztreonam $(30 \mu \mathrm{g})$, colistin sulfate $(50 \mu \mathrm{g})$, ciprofloxacin $(5 \mu \mathrm{g})$, nalidixic acid (30 $\mu \mathrm{g})$, gentamicin (15 $\mu \mathrm{g})$, netilmicin $(10 \mu \mathrm{g})$ and tobramycin $(10 \mu \mathrm{g})$ (Bio-Rad, France). The diameters of the antibiotic susceptibility halos were recorded according to the recommendations of EUCAST. Intermediate (I) susceptibility of pathovars was classified as resistant (R).

\section{Detection of antibiotic resistance genes}

The strains that were resistant to imipenem and amoxicillin/clavulanate were PCR screened. DNA for PCR analysis was extracted from the isolates using the heat lysis method ${ }^{19}$. A loopful of bacterial growth from Mueller Hinton agar (Liofilchem, Italy) plate was suspended in $1 \mathrm{ml}$ of sterile water, and the mixture was boiled for $10 \mathrm{~min}$ at $+100{ }^{\circ} \mathrm{C}$ and 
centrifuged for $10 \mathrm{~min}$ at $12000 \mathrm{rpm}$ at $+4^{\circ} \mathrm{C}$. The obtained supernatant was collected and used for PCR reactions. Multiplex PCR assays were carried out using oligonucleotides (Table 3) to detect the presence of genes of the bla ${ }_{\mathrm{KPC}}, b a_{\mathrm{VIM}}, b l a_{\mathrm{IMP}}, b l a_{\mathrm{TEM}}, b l a_{\mathrm{SHV}}, b l a_{\mathrm{OXA}}$ and bla ${ }_{\mathrm{CTX}-\mathrm{M}}$ types in all E. coli and Salmonella strains of the study.

About $2.5 \mu \mathrm{l}$ of supernatant were added to $22.5 \mu \mathrm{l}$ reaction mixture containing $5 \mathrm{U}$ of Taq DNA polymerase (Accu Power, Korea), deoxyribonucleic triphosphate $(10 \mathrm{mM})$, buffer GC (10X), $\mathrm{MgCl} 2(25 \mathrm{mM})$, and PCR primers $(10 \mu \mathrm{M})$. We performed PCR conditions as followed: $5 \mathrm{~min}$ at $+94^{\circ} \mathrm{C}$, followed by 35 amplification cycles of $+94^{\circ} \mathrm{C}$ for $30 \mathrm{~s}, 59 \pm 4^{\circ} \mathrm{C}$ for $60 \mathrm{~s}$ and $+72^{\circ} \mathrm{C}$ for $60 \mathrm{~s}$ with a final extension of $+72^{\circ} \mathrm{C}$ for $10 \mathrm{~min}$ on a thermal cycler (Gene Amp 9700, Applied Biosystems). Our reaction products were separated by electrophoresis in (1.5\% weight/volume) agarose gel, stained with a Redsafe solution (Prolabo, France) and visualized under ultraviolet (UV) light (Gel Logic 200).

\section{Ethics approval and consent to participate}

Permission to conduct the study was obtained from the hospital authorities of Burkina Faso, and informed verbal consent was obtained from the parents/guardians of every child before sample collection. The National Ethical Committee (s) of Burkina Faso (N $\left.{ }^{\circ} 2009-39\right)$ approved the study protocol.

\section{RESULTS}

\section{Bacterial isolates}

Of the 275 stool samples, five isolates were confirmed as $E$. coli strains: 3 EAEC, and 2 atypical EPEC. Nine Salmonella isolates were detected belonging to the following serotypes: Salmonella Poona, $S$. Typhimurium, $S$. Ouakam, S. Virchow, $S$. Duisburg and $S$. Hvittingfoss.

\section{Antimicrobial resistance}

The five E. coli strains were resistant to amoxicillinclavulanic acid, amoxicillin and tetracycline (5/5); four strains were resistant to trimetoprim-sulfametoxazol, colistin-sulfate and piperacillin (4/5); three strains showed resistance to cefotaxim, ceftriaxone, aztreonam, cefixime and cefepime (3/5). Whereas, resistance to chloramphenicol and also to imipenem was shown in two of isolates $(2 / 5)$.

All the nine Salmonella strains were resistant to amoxicillin (9/9), eight were resistant to amoxicillin-clavulanic acid (8/9), six were resistant to tetracycline, cefixime and cefepime (6/9); five were resistant to ceftriaxone, cefotaxim and colistin-sulfate (5/9). Less than five strains were resistant to aztreonam, trimetoprim-sulfametoxazol and piperacillin while no resistance was shown to imipenem (Fig. 2).

\section{Carbapenemase genes}

The results of PCR amplification of bla $a_{\mathrm{KPC}}, b l a_{\mathrm{VIM}}, b l a_{\mathrm{IMP}}$, $b_{\text {bEM, }}$ bla $a_{\mathrm{SHV}}, b l a_{\mathrm{OXA}}$ and bla $a_{\mathrm{CTX}-\mathrm{M}}$ genes in $E$. coli and Salmonella isolates are given in table 4. bla ${ }_{\mathrm{KPC}}$ gene (Fig. 4), bla $_{\text {VIM }}$ gene and bla $_{\mathrm{IMP}-2}$ gene were carried by two E. coli isolates which were resistant to imipenem. bla $a_{\text {XxA }}$ gene (Fig. 3 ) was found in all the five E. coli strains (5/5) and in three

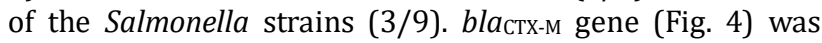
shown in one E. coli strain and in none of the Salmonella. bla ${ }_{\mathrm{TEM}}$ and blashv were reported in none of the E. coli and Salmonella strains.

All $E$. coli strains were isolated in children of one year old while the sex distribution was $4 / 5$ for male and $1 / 5$ for female. The Salmonella were reported in children of one year old (4/9), two years old (2/9) and three years old (3/9) with a sex distribution of $5 / 9$ for male and $4 / 9$ for female (table $3)$.

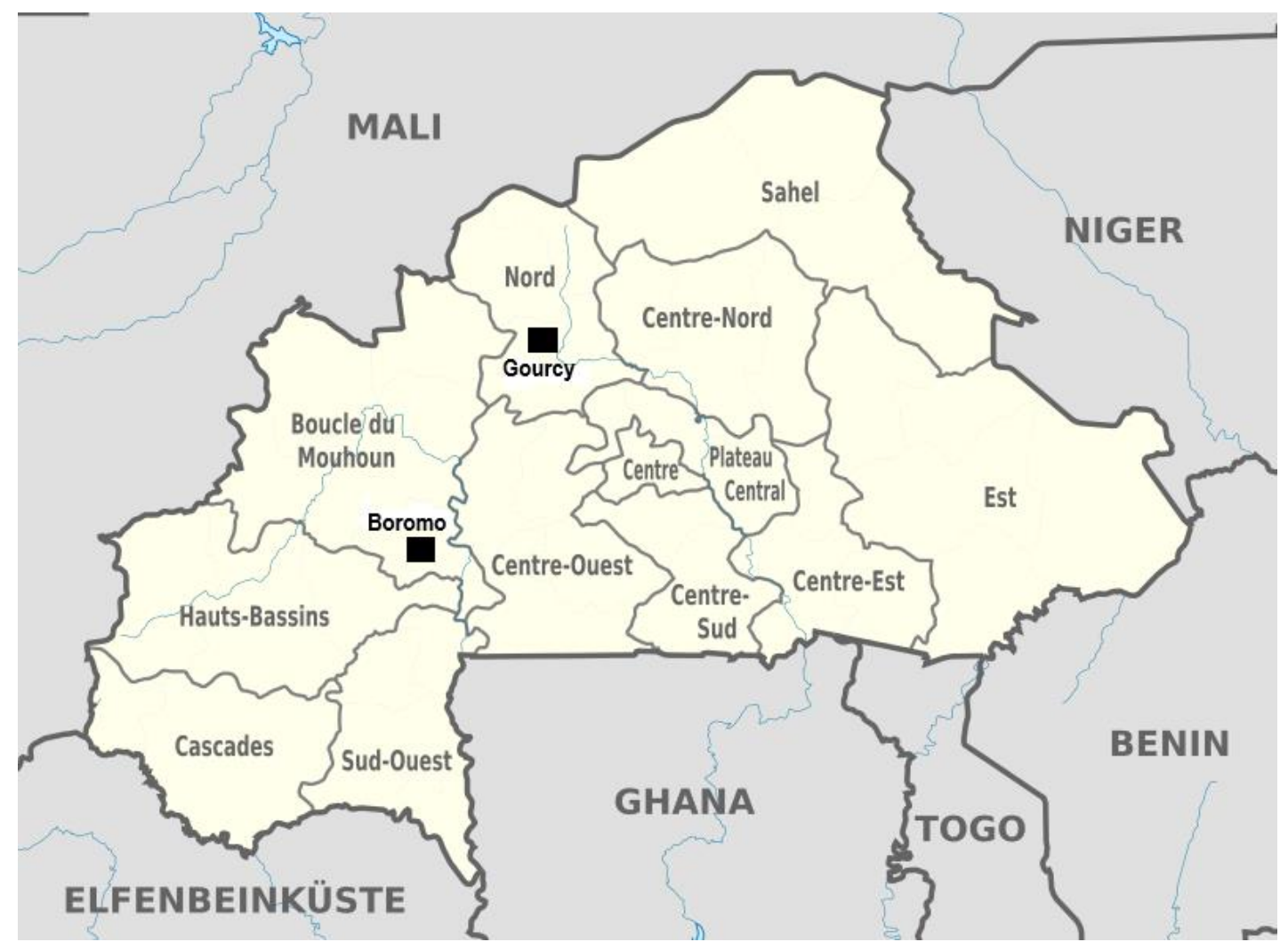

Figure 1: Map of Burkina Faso. In square black dots = Gourcy and Boromo where the study was conducted. 


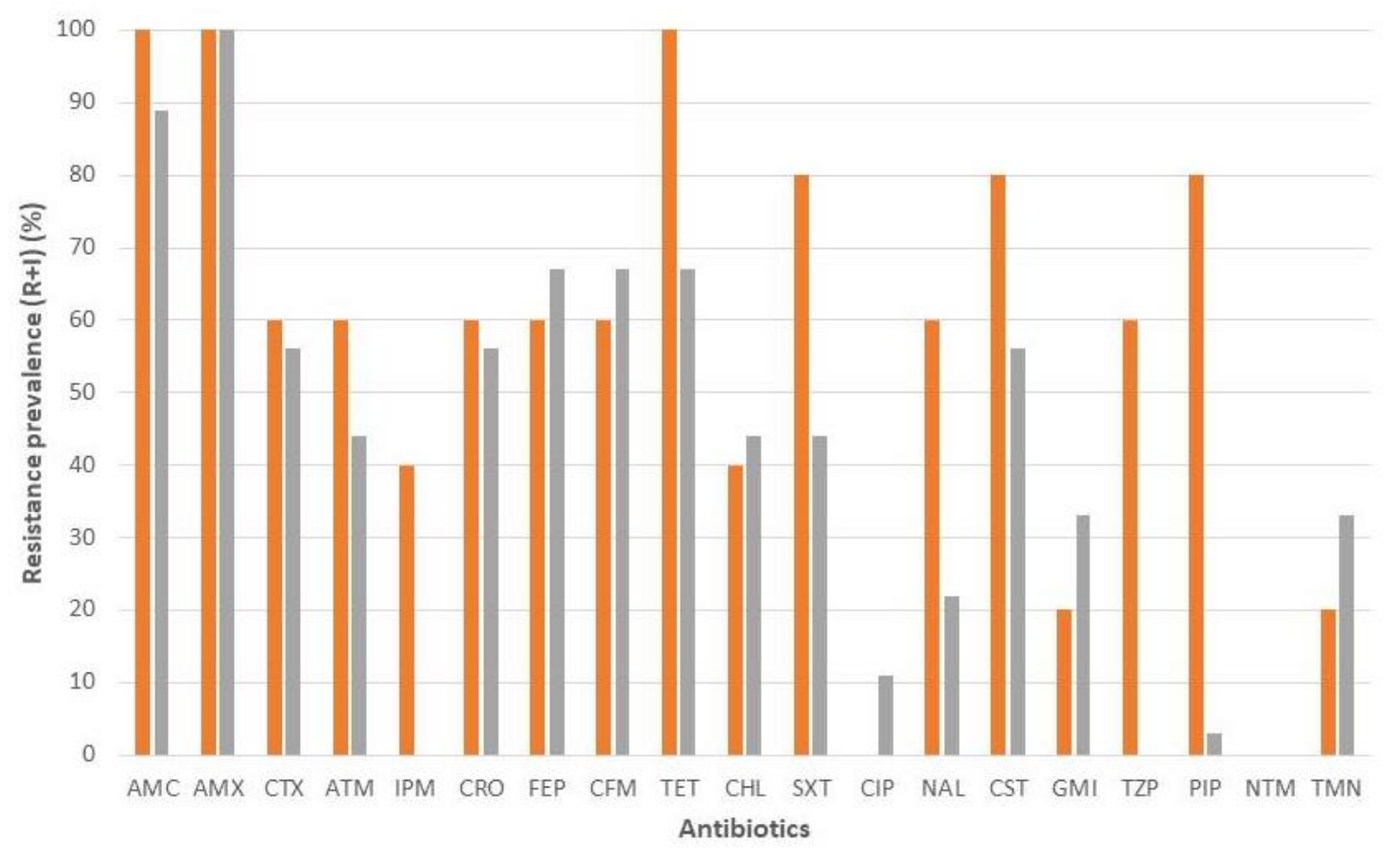

E. coli Salmonella

Figure 2: Resistance to individual antimicrobial among E. coli and Salmonella strains.

Figure legend: $\mathrm{AMC}=$ Amoxicillin- clavulanic acid, $\mathrm{AMX}=$ Amoxicillin, $\mathrm{CTX}=$ Cefotaxime, $\mathrm{ATM}=$ Aztreoname, IPM = Imipenem, CRO $=$ Ceftriaxone, FEP $=$ Cefepime, CFM $=$ Cefixime, TET $=$ Tetracycline, CHL $=$ Chloramphenicol, SXT $=$ Trimethoprim sulfametoxazole CIP $=$ Ciprofloxacine, NAL $=$ nalidixic acid, CST $=$ Colistin sulfate, GMI $=$ Gentamicin, TZP = Piperacillintazobactam, PIP = Piperacillin, NTM = Netilmicin, TMN = Tobramycin, I = Intermediate, $\mathrm{R}=$ Resistant.

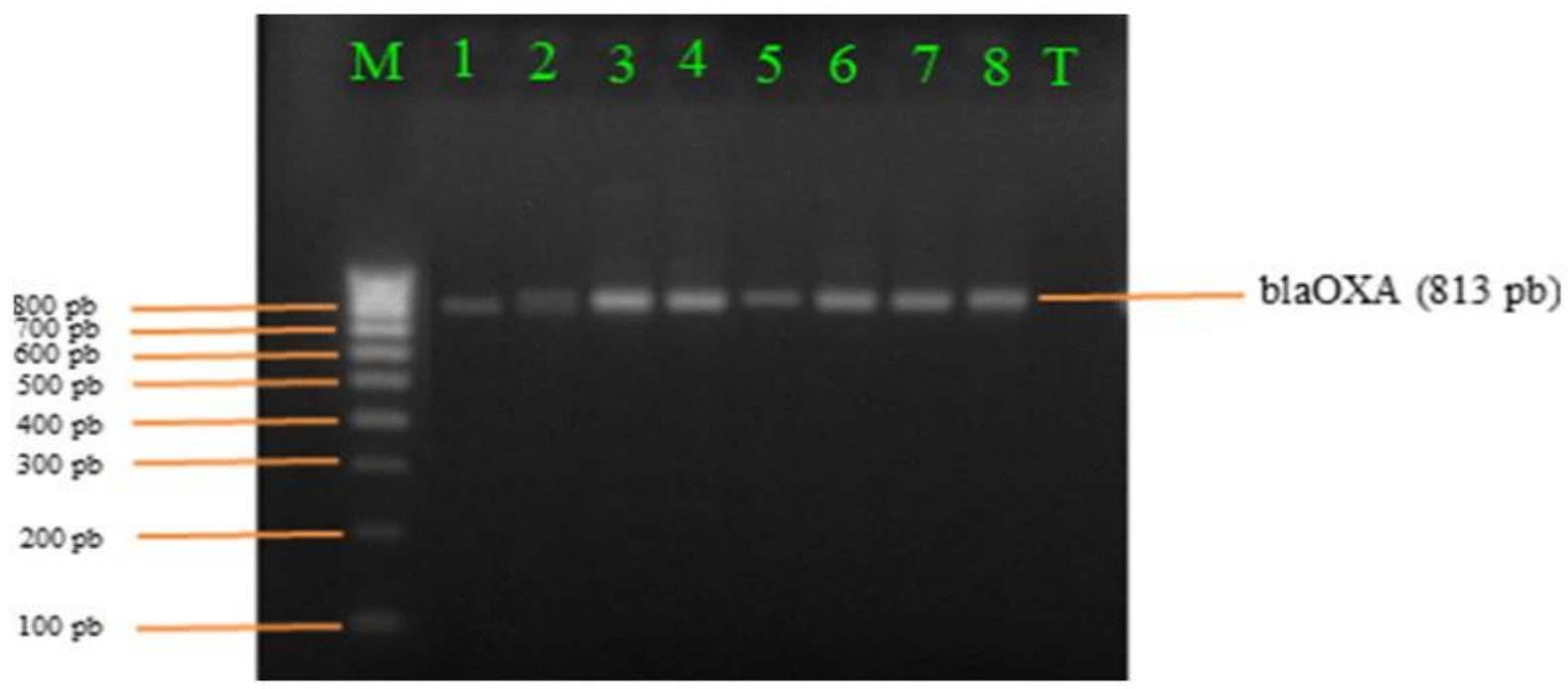

Figure 3: blaOXA gene detected in E. coli.

Figure legend : Lane M : hyperlader (100 bp), Lane 1 : blaOXA positive control (813 pb), Lane 2-8 : positive samples for blaOXA gene (813 pb), Lane $\mathrm{T}$ : negative sample. 


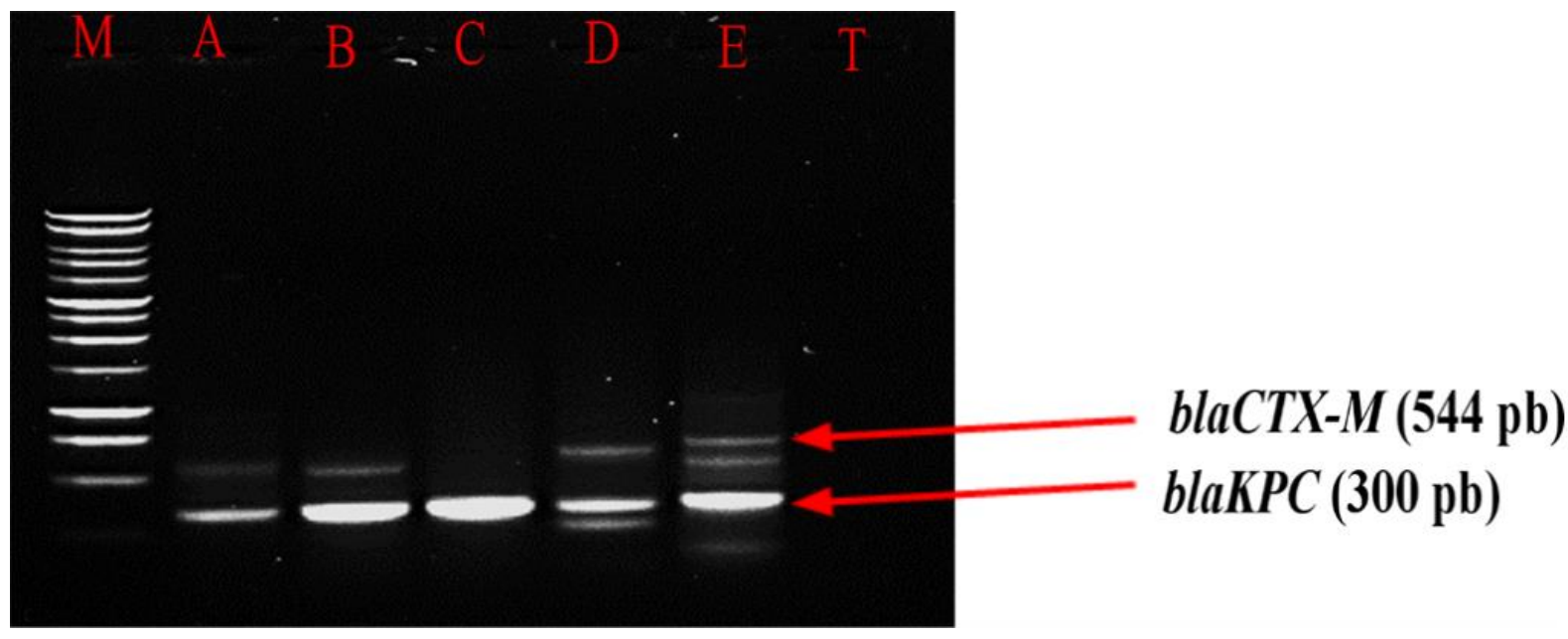

Figure 4. blaCTX-M and blaKPC genes detected in E. coli.

Figure legend: Lane $\mathrm{M}$ = hyperlader $100 \mathrm{bp}$; Lane $\mathrm{A}$ = blaCTX-M positive control (544 pb), Lane B, $\mathrm{D}$ et $\mathrm{E}=$ positive samples for blaCTX-M gene (544 pb), Lane B, C, D et E = positive samples for blaKPC gene (300 pb), T: negative sample.

Table 1 : Oligonucleotides primers used for multiplex PCR reaction

\begin{tabular}{|c|c|c|c|c|c|}
\hline Pathotype & Target gene & Primer sequence (5' to 3 ') & $\begin{array}{l}\text { Size } \\
\text { (bp) }\end{array}$ & $\begin{array}{c}{[\mathrm{C}]} \\
(\mu \mathrm{M})\end{array}$ & Reference \\
\hline \multirow[t]{2}{*}{ Typical EPEC } & bfpB & MP3-bfpB-F: GACACCTCATTGCTGAAGTCG & 910 & 0.1 & [16] \\
\hline & & MP3-bfpB-R:CCAGAACACCTCCGTTATGC & & 0.1 & \\
\hline \multirow[t]{6}{*}{ EHEC and EPEC } & $e a e A$ & eae-F:TCAATGCAGTTCCGTTATCAGTT & 482 & 0.1 & [16] \\
\hline & & eae-R:GTAAAGTCCGTTACCCCAACCTG & & 0.1 & \\
\hline & escV & MP3-escV-F:ATTCTGGCTCTCTTCTTCTTTATGGCTG & 544 & 0.4 & [16] \\
\hline & & MP3-escV-R:CGTCCCCTTTTACAAACTTCATCGC & & 0.4 & \\
\hline & Ent & ent-F:TGGGCTAAAAGAAGACACACTG & 629 & 0.4 & [16] \\
\hline & & ent-R:CAAGCATCCTGATTATCTCACC & & 0.4 & \\
\hline \multirow[t]{6}{*}{ EHEC } & EHEC-hly & hlyEHEC-F: TTCTGGGAAACAGTGACGCACATA & 688 & 0.1 & [15] \\
\hline & & hlyEHEC-R: TCACCGATCTTCTCATCCCAATG & & 0.1 & \\
\hline & Stx1 & MP4-stx1A-F:CGATGTTACGGTTTGTTACTGTGACAGC & 244 & 0.2 & [16] \\
\hline & & MP4-stx1A-R:AATGCCACGCTTCCCAGAATTG & & 0.2 & \\
\hline & Stx2 & MP3-stx2AF:GTTTTGACCATCTTCGTCTGATTATTGAG & 324 & 0.4 & [16] \\
\hline & & MP3-stx2A-R:AGCGTAAGGCTTCTGCTGTGAC & & 0.4 & \\
\hline \multirow[t]{7}{*}{ EAEC } & astA & MP-astA-F TGCCATCAACACAGTATATCCG & 102 & 0.4 & [16] \\
\hline & & MP2-astA-R ACGGCTTTGTAGTCCTTCCAT & & 0.4 & \\
\hline & $\operatorname{aggR}$ & MP2-aggR-F:ACGCAGAGTTGCCTGATAAAG & 400 & 0.2 & [16] \\
\hline & & MP2-aggR-R:AATACAGAATCGTCAGCATCAGC & & 0.2 & \\
\hline & Pic & MP2-pic-F:AGCCGTTTCCGCAGAAGCC & 1111 & 0.2 & [16] \\
\hline & & MP2-pic-R:AAATGTCAGTGAACCGACGATTGG & & 0.2 & \\
\hline & $\operatorname{invE}$ & MP2-invE-F:CGATAGATGGCGAGAAATTATATCCCG & 766 & 0.2 & [16] \\
\hline \multirow[t]{3}{*}{ EIEC } & & MP2-invE-R:CGATCAAGAATCCCTAACAGAAGAATCAC & & 0.2 & \\
\hline & ipaH & ipaH-F: GAAAACCCTCCTGGTCCATCAGG & 437 & 0.1 & [17] \\
\hline & & ipaH-R:GCCGGTCAGCCACCCTCTGAGAGTAC & & 0.1 & \\
\hline \multirow[t]{6}{*}{ ETEC } & elt & MP2-LT-F: GAACAGGAGGTTTCTGCGTTAGGTG & 655 & 0.1 & [16] \\
\hline & & MP2-LT-R: CTTTCAATGGCTTTTTTTTGGGAGTC & & 0.1 & \\
\hline & estA & MP4-STIa-F: CCTCTTTTAGYCAGACARCTGAATCASTTG & 157 & 0.4 & [16] \\
\hline & & MP4-STIa-R : CAGGCAGGATTACAACAAAGTTCACAG & & 0.4 & \\
\hline & estB & MP2-STI-F : TGTCTTTTTCACCTTTCGCTC & 171 & 0.2 & [16] \\
\hline & & MP2-STI-R CGGTACAAGCAGGATTACAACAC & & 0.2 & \\
\hline \multirow[t]{2}{*}{ E. coli } & uidA & MP2-uidA-F:ATGCCAGTCCAGCGTTTTTGC & 1487 & 0.2 & [17] \\
\hline & & MP2-uidA-R:AAAGTGTGGGTCAATAATCAGGAAGTG & & 0.2 & \\
\hline
\end{tabular}


Table 2 : Zones of inhibition of the tested antibiotics

\begin{tabular}{|c|c|c|c|c|c|}
\hline \multirow{2}{*}{ Families } & & \multirow{2}{*}{ Antibiotics } & \multirow{2}{*}[C]{$^{\mathrm{a}}(\mu \mathrm{g})$} & \multicolumn{2}{|c|}{ Ǿ b(mm) } \\
\hline & & & & $\mathbf{R}(\emptyset<)$ & 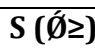 \\
\hline & Aminopenicillins & Amoxicillin- clavulanic acid (AMC) & 30 & 19 & 19 \\
\hline & & Amoxicillin (AMX) & 25 & 19 & 19 \\
\hline & & Piperacillin (PIP) & 75 & 17 & 20 \\
\hline & & Piperacillin-tazobactam (TZP) & $100 / 10$ & 17 & 20 \\
\hline & Cephalosporins C3G & Ceftriaxone (CRO) & 30 & 20 & 23 \\
\hline & & Cefixime (CFM) & 10 & 17 & 17 \\
\hline \multirow[t]{4}{*}{$\beta$-lactams } & & Cefotaxime (CTX) & 30 & 17 & 20 \\
\hline & Cephalosporines C4G & Cefepime (FEP) & 30 & 21 & 24 \\
\hline & Monobactam & Aztreonam (ATM) & 30 & 21 & 24 \\
\hline & Carbapenemes & Imipenem (IPM) & 10 & 16 & 22 \\
\hline Quinolones & & Nalidixic acid (NAL) & 30 & 14 & 19 \\
\hline Fluoroquinolones & & Ciprofloxacin (CIP) & 5 & 19 & 22 \\
\hline Cyclines & & Tetracycline (TET) & 30 & 15 & 18 \\
\hline Phenicols & & Chloramphenicol (CHL) & 30 & 17 & 17 \\
\hline Sulfamides & & Trimethoprim-sulfamethoxazole (SXT) & $1.25 / 23.75$ & 13 & 16 \\
\hline \multirow[t]{2}{*}{ Polymyxines } & & Colistin sulfate (CST) & 50 & 15 & 15 \\
\hline & & Gentamycin (GMI) & $15(10 \mathrm{IU})$ & 14 & 17 \\
\hline \multirow[t]{2}{*}{ Aminoglycosides } & & Netilmicin (NTM) & 10 & 12 & 15 \\
\hline & & Tobramycin (TMN) & 10 & 14 & 17 \\
\hline
\end{tabular}

Table 3: Oligonucleotides used to amplify carbapenemases genes

\begin{tabular}{|c|c|c|c|}
\hline Primer name & Target genes & Primers sequence (5'to3') & Size (bp) \\
\hline KPC- F & \multirow{2}{*}{ bla $\mathrm{KPC} 2_{2}$} & GCT CAG GCG CAA CTG TAA G & \multirow{2}{*}{300} \\
\hline KPC-R & & AGC ACA GCG GCA GCA AGA AAG & \\
\hline VIM- F & \multirow{2}{*}{ blavim } & CAG ATT GCC GAT GGT GTT TGG & \multirow{2}{*}{390} \\
\hline VIM-R & & AGG TGG GCC ATT CAG CCA GA & \\
\hline IMP- F & \multirow{2}{*}{$b^{\prime l a} a_{\mathrm{IMP}}$} & GGA ATA GAG TGG CTT AAT TCTC & \multirow{2}{*}{232} \\
\hline IMP-R & & GTG ATG CGT CYC CAA YTT CAC T & \\
\hline TEM- F & \multirow{2}{*}{$b l a_{\mathrm{TEM}}$} & ATG AGT ATT CAA CAT TTC CG & \multirow{3}{*}{1080} \\
\hline TEM-R & & CCA ATG CTT ATT CAG TGA GG & \\
\hline SHV- F & \multirow{2}{*}{$b l a_{\mathrm{SHV}}$} & TTA TCT CCC TGT TAG CCA CC & \\
\hline SHV-R & & GAT TTG CTG ATT TCG CTC GG & \multirow[t]{2}{*}{768} \\
\hline OXA- F & \multirow{2}{*}{ bla } & ATG AAA AAC ACA ATA CAT ATC & \\
\hline OXA-R & & AAT TTA GTG TGT TTA GAA TGG & \multirow[t]{2}{*}{813} \\
\hline CTX-M- F & \multirow{2}{*}{ bla ${ }_{\mathrm{CTX- \textrm {M }}}$} & ATG TGC AGY ACC AGT AAR GT & \\
\hline CTX-M-R & & TGG GTR AAR TAR GTS ACC AGA & 544 \\
\hline
\end{tabular}


Table 4: Carbapenemase-producing Enterobacteriaceae

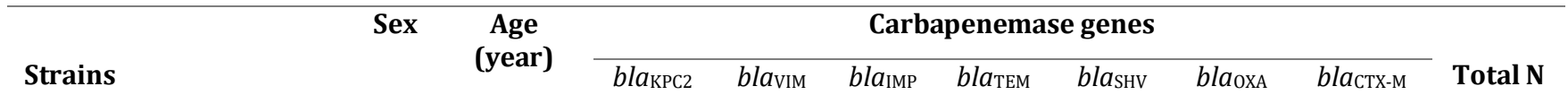

Escherichia coli pathotyps

\begin{tabular}{|c|c|c|c|c|c|c|c|c|c|c|}
\hline 025 B (EAEC) & M & 1 & - & - & - & - & - & + & - & 1 \\
\hline 039B (EAEC) & $\mathrm{F}$ & 1 & - & - & - & - & - & + & - & 1 \\
\hline 043B (Atypical EPEC) & M & 1 & + & + & + & - & - & + & - & 4 \\
\hline 044B (EAEC) & $\mathrm{M}$ & 1 & + & + & + & - & - & + & + & 5 \\
\hline 046B (Atypical EPEC) & M & 1 & - & - & - & - & - & + & - & 1 \\
\hline
\end{tabular}

Salmonella serovars

\begin{tabular}{|c|c|c|c|c|c|c|c|c|c|c|}
\hline 084B (S. Duisburg) & M & 3 & - & - & - & - & - & + & - & 1 \\
\hline 057B (S. Poona) & $\mathrm{M}$ & 2 & - & - & - & - & - & - & - & 0 \\
\hline 066B (S. Typhimurium) & M & 1 & - & - & - & - & - & - & - & 0 \\
\hline 068B (S. Typhimurium) & $\mathrm{M}$ & 2 & - & - & - & - & - & + & - & 1 \\
\hline 078B (S. Ouakam) & $\mathrm{M}$ & 1 & - & - & - & - & - & + & - & 1 \\
\hline 063G (S. Hvittingfoss) & $\mathrm{F}$ & 1 & - & - & - & - & - & - & - & 0 \\
\hline 087G (S. Poona) & $\mathrm{F}$ & 1 & - & - & - & - & - & - & - & 0 \\
\hline 112G1 (S. Virchow) & $\mathrm{F}$ & 3 & - & - & - & - & - & - & - & 0 \\
\hline 112G2 (S. Virchow) & $\mathrm{F}$ & 3 & - & - & - & - & - & - & - & 0 \\
\hline
\end{tabular}

\section{DISCUSSION}

Increasing numbers of antibiotic-resistant Enterobacteriaceae are responsible of serious problems in infection control. This phenomenon also contributes to the global spread of Carbapenemase- producing bacteria becoming therefore especially worrisome 20 . It has been shown that Enterobacterales spp., such as Escherichia coli and Klebsiella pneumoniae, are common human pathogens and asymptomatic colonizers of the human gastrointestinal tract and environmental niches 21 . Our study reported for the first time the occurrence of Carbapenemase-producing $E$. coli and Salmonella in children with diarrhea in rural settings of Burkina Faso.

The isolated strains were mainly resistant to amoxicillinclavulanic acid, amoxicillin, tetracycline, trimetoprimsulfametoxazol, colistin-sulfate, piperacillin, cefotaxime, ceftriaxone, aztreonam, cefixime and cefepime (between $60 \%$ and $100 \%$ ). Particularly, two E. coli harbored resistance patterns to imipenem. In contrast, no resistance to imipenem was observed in Salmonella strains. Similar results concerning $E$. coli resistance to imipenem were reported in India ${ }^{12}$. All isolated E. coli and Salmonella were $100 \%$ sensitive to netilmicin in agreement with data reported in Bangladesh 22.

In the present study, the most detected carbapenemase was bla 0 xa which was encoded by eight of the isolates (57.14\%). In agreement to our result, a recent review showed that OXA-48-like enzymes associated with Enterobacteriaceae are one of the most concerning developments in carbapenem resistance in the last decade and are still globally ascending ${ }^{23}$. bla $a_{\mathrm{CTX-M}}$ gene was shown in one $E$. coli strain while bla TEM and blashv were reported in none of the strains. Unlike our results, studies conducted in India reported a high prevalence of CTX-M-type ESBL among ESBL-E. coli isolated from clinical specimens $24,25$.

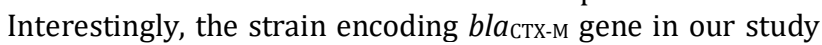
also harbored bla oxa gene. Indeed, enteric Gram-negative bacteria with the blaOXA-48-like genes could co-harbor genes encoding ESBL (bla $\left.{ }_{\mathrm{CTX}-\mathrm{M}}, b l a_{\mathrm{SHV}}, b l a_{\mathrm{TEM}}\right){ }^{26}$. bla $a_{\mathrm{KPC}}$, $b_{\text {bla }}$ ज and bla $a_{\mathrm{Imp}-2}$ were carried by two E. coli isolates while no Salmonella strains harboured these genes. Similarly, a recent study reported no blaKPC, blaVIM and blaIMP genes on carbapenemase producing Salmonella enterica isolates in the United Kingdom but reported 2 blaOXA48 strains and one blaNDM on the same isolates ${ }^{27}$. This is expected because carbapenemase-producing Salmonella strains are rarely isolated. In contrast, resistance to carbapenems was observed in CIP-R Salmonella KentuckyX1-ST198-SGI1 isolates in which carbapenemases blaVIM-2 and blaOXA-48 have been detected ${ }^{28}$.

Our results show that carbapenemase-producing Enterobacterales (CPE) remain one of the most urgent healthcare threats. Indeed, carbapenemase-encoding genes are already widespread in many parts of the world ${ }^{23}$. A recent study on wastewater used for urban agriculture in Ouagadougou (Burkina Faso) concluded that raw sewage used as fertilizer could be contributing to the spread of resistance bacteria among humans and animals 29. Furthermore, a study has shown that bacteria producing carbapenemase are currently spreading among pets 3 and because of the proximity between humans and animals, these bacteria can contaminate humans. For example, it has been shown that poultry flocks contribute to the global dissemination of Salmonella Kentucky ST198-X1-SGI1CIP-R strain in developing countries ${ }^{28}$. Since subsistence, farming and animal husbandry are the primary economic activities for the local populations in Boromo and Gourcy, the spread of these bacteria poses serious health concerns. 
Three specific genes were detected in two E. coli strains: Klebsiella pneumoniae carbapenemase (KPC), Verona integrin-encoded metallo- $\beta$-lactamase (VIM) and Imipenemase (IMP-2). To our best of knowledge, this is the first report of bla $a_{\mathrm{KPC}}$ gene in E. coli in Burkina Faso. However, KPC producers have been described, mostly from nosocomial $K$. pneumoniae isolates, and E. coli strains in Israel but also from other enterobacterial species ${ }^{30}$. Indeed, since their identification the first time in the USA in 1996, Klebsiella pneumoniae carbapenemases (KPCs) have spread internationally among Gram-negative bacteria, especially $K$. pneumoniae, although their precise epidemiology is diverse across countries and regions worldwide 31 . Furthermore, because of its extensively identification worldwide, $K$. pneumoniae may have contributed to the spread of the blaKPC genes ${ }^{32}$.

As far as the class B metallo- $\beta$-lactamases (MBLs) is concerned, our results corroborate the existing reports. Endemicity of VIM- and IMP-type enzymes has been reported in Greece, Taiwan and Japan 33, 8, although outbreaks and single reports of VIM and IMP producers have been shown in many other countries 33 .

It has been shown that carbapenemases can hydrolyze almost all $\beta$-lactams, and are easily transferable among enterobacterial species 34 . These genes are found in multidrug-resistant isolates consistent with the result found in the present study 34. Therefore, its spread in Enterobacteriaceae is a public health issue. For example, invasive infections by carbapenem-resistant strains have been found to be associated with high morbidity and mortality rates 35 .

Otherwise, several risk factors of colonization and infection with carbapenemase-producing Enterobacterales (CPE) including severe underlying illness, prolonged hospital stay, the presence of invasive medical devices, and antibiotic use have been shown ${ }^{36-39}$. According to previous studies, CPE have been associated with adverse clinical and economic outcomes such as increased mortality, increased length of stay, setting up an effective therapy scheme, decreased functional status on discharge, and increased cost of health care ${ }^{40-43}$. Young children (those under one year old) were severely infected with carbapenem-resistant E. coli. This is a matter of public health issues because the emergence of MBL-producing bacteria greatly limits treatment options 44 . The most frequent MBLs reported to date belong to the VIM and IMP types and have been described extensively worldwide ${ }^{45}$.

The main limitation of the present study consists of the low number of isolates which makes generalizability difficult. Morever, the use of phenotypic approach limited to imipenem MIC is not adapted for the detection of all carbapenemase type. For instance, enterobacteria strains carrying bla0XA48 carbapenemase could present low imipenem MIC $(0.5 \mathrm{mg} / \mathrm{L})$ suggesting the use of temocillin for phenotypic detection of blaOXA48 46 .

\section{CONCLUSIONS}

Infections by carbapenem-resistant bacteria are difficult to treat successfully. This study highlights the need for rapid identification of MBL-producing Gram-negative species both for appropriate treatment and for timely implementation of infection control measures. In developing countries like Burkina Faso, phenotypic methods may be useful for routine detection of Carbapenemase production, particularly when PCR is not available.

\section{ACKNOWLEDGMENT}

We thank the "Réseau de Recherche sur les Maladies Entériques à Potentiel Épidémique en Afrique de l'Ouest (REMENTA)" for assistance with PCR reagents, the "Centre National de Recherche et de Formation sur le Paludisme (CNRFP)/Ouagadougou, Burkina Faso" and the "Centre National de Référence pour les Antibiotiques (CNRAntibiotiques)/Institut Pasteur de Côte d'Ivoire" for technical support.

\section{CONFLICT OF INTEREST}

The authors stipulate that they have no conflict of interest in regard to this study.

\section{REFERENCES}

1. World Health Organization (WHO). Antimicrobial resistance; 2018.

https://www.who.int/medicines/areas/rational_use/who-amramc-report-20181109.pdf

2. Gauthier L, Dortet L, Cotellon G, Creton E, Cuzon G, et al. Diversity of carbapenemase-producing Escherichia coli isolates, France 2012-2013. Antimicrob Agents Chemother. 2018; 62: pii: e00266-18.

3. Yousfi M, Touati A, Mairi A, Creton E, Cuzon G, Ponties V, et al Emergence of Carbapenemase-Producing Escherichia coli Isolated from Companion Animals in Algeria. 2016; Microbial Drug Resist. 22:342-346.

4. Li XZ, Mehrotra M, Ghimire S, Adewoye L. Beta-Lactam resistance and beta-lactamases in bacteria of animal origin. Vet Microbiol. 2007; 121:197-214.

5. Tzouvelekis LS, Markogiannakis A, Psichogiou M, Tassios PT, Daikos GL. Carbapenemases in Klebsiella pneumoniae and other Enterobacteriaceae: an evolving crisis of global dimensions. Clin Microbiol Rev. 2012; 25:682-707.

6. Nordmann P, Dortet L, Poirel L. Carbapenem resistance in Enterobacteriaceae: Here is the storm! Trends Mol Med. 2012; 18:263-272.

7. Nordmann P, Cornaglia G. Carbapenemase-producing Enterobacteriaceae: A call for action! Clin Microbiol Infect. 2012; 18:411-412.

8. Queenan AM, Bush K. Carbapenemases: the versatile $\beta$ lactamases. Clin Microbiol Rev. 2007; 20:440-458.

9. Ruppé É, Woerther P-L, Barbier F. Mechanisms of antimicrobial resistance in gram-negative bacilli. Ann Intensive Care 2015; 5 (21) Article 61.

10. Lowman W, Bamford C, Govind C, Swe Swe Han K, Kularatne R, Senekal M, et al. The SASCM CRE-WG: consensus statement and working guidelines for the screening and laboratory detection of carbapenemase-producing Enterobacteriaceae. South Afr J Infect Dis. 2014; 29:5-11.

11. Sherchan JB, Hayakawa K, Miyoshi-Akiyama T, Ohmagari N, Kirikae T, Nagamatsu M, et al. Clinical Epidemiology and Molecular Analysis of Extended-Spectrum B-LactamaseProducing Escherichia coli in Nepal: Characteristics of Sequence Types 131 and 648. Antimicrob Agents Chemother. 2015; 59:3424-32.

12. Mariappan S, Sekar U, Kamalanathan A Carbapenemase-producing Enterobacteriaceae: Risk factors for infection and impact of resistance on outcomes. Int J App Basic Med Res. 2018; 7:32-39.

13. Ortega A, Saez D, Bautista V, Fernandez-Romero S, Lara N, Aracil $\mathrm{B}$, et al. Carbapenemase-producing Escherichia coli is becoming more prevalent in Spain mainly because of the polyclonal dissemination of OXA-48. J Antimicrob Chemother. 2016; 71: 2131-38.

14. Popoff MY, Bockemuhl J, Gheesling LL. Supplement 2002 (no. 46) to the Kauffmann-White scheme. Res Microbiol. 2004. 155:568-70.

15. Antikainen J, Tarkka E, Haukka K, Siitonen A, Vaara M, Kirveskari J. New 16 plex PCR method for rapid detection of Diarrheagenic Escherichia coli directly from stool samples. Europ J Clin Microbiol Infect Dis. 2009; 28: 899-908.

16. Müller D, Greune L, Heusipp G, Karch H, Fruth A, Tschäpe H, et al. Identification of unconventional intestinal pathogenic Escherichia coli isolates expressing intermediate virulence factor profiles by using a novel single-step multiplex PCR. Appl Environ Microbiol. 2007; 73: 3380-90. 
17. Vidal M, Kruger E, Durán C, Lagos R, Levine M, Prado V, et al. Single Multiplex PCR Assay To Identify Simultaneously the Six Categories of Diarrheagenic Escherichia coli Associated with Enteric Infections. J Clin Microbiol. 2005; 43: 5362-65.

18. European Committee on Antimicrobial Susceptibility Testing (EUCAST). Recommandation 2017. Éd. V.1.0 Mars. pp 1-127. https://www.eucast.org/

19. Moyo SJ, Maselle SY, Matee MI, Langeland N, Mylvaganam H. Identification of Diarrheagenic Escherichia coli isolated from infants and children in Dar es Salaam, Tanzania. BMC Infect Dis. 2007; 7: 92.

20. Nordmann P, Naas T, Poirel L. Global spread of carbapenemaseproducing Enterobacteriaceae. Emerg Infect Dis. 2011; 17:17911798.

21. Mathers AJ, Vegesana K, German-Mesner I, Ainsworth J, Pannone A, Crook DW, et al. Risk factors for Klebsiella pneumoniae carbapenemase (KPC) gene acquisition and clinical outcomes across multiple bacterial species. J Hospit Infect. 2020; 104: 456-468.

22. Hossain MZ, Naher A, Hasan P, Mozazfia KT, Tasnim H, Ferdush $\mathrm{Z}$, et al. Prevalent bacteria and their sensitivity and resistance pattern to antibiotics: a study in Dhaka medical college hospital. J Dhaka Med Coll. 2017; 26: 52-64.

23. Halat DH, Moubareck CA. The Current Burden of Carbapenemases: Review of Significant Properties and Dissemination among Gram-Negative Bacteria. Antibiotics 2020; 9, 186.

24. Nisha KV, Veena SA, Rathika SD, Vijaya SM, Avinash SK. Antimicrobial susceptibility, risk factors and prevalence of bla cefotaximase, temoneira, and sulfhydryl variable genes among Escherichia coli in community-acquired pediatric urinary tract infection. J Lab Physic. 2017; 9:156-62.

25. Devi LS, Broor S, Rautela RS, Grover SS, Chakravarti A, Chattopadhya D. Increasing Prevalence of Escherichia coli and Klebsiella pneumoniae Producing CTX-M-Type Extended-Spectrum Beta-Lactamase, Carbapenemase, and NDM-1 in Patients from a Rural Community with Community Acquired Infections: A 3-Year Study. Int J App Basic Med Res. 2020; 10:156-163.

26. Jean S-S, Lee W-S, Lam C, Hsu C-W, Chen R-J, Hsueh P-R. Carbapenemase-producing Gram-negative bacteria: Current epidemics, antimicrobial susceptibility and treatment options. Future Microbiol. 2015; 10: 407-425.

27. Day MR, Meunier D, Doumith M, de Pinna E, Woodford N, Hopkins KL. Carbapenemase-producing Salmonella enterica isolates in the UK. J Antimicrob Chemother. 2015; 2165-2167.

28. Le Hello S, Bekhit A, Granier SA, Barua H, Beutlich J, Zajac M, et al. The global establishment of a highly-fluoroquinolone resistant Salmonella enterica serotype Kentucky ST198 strain. Front Microbiol. 2013; 4: 395.

29. Bougnom BP, Zongo C, McNally A, Ricci V, Etoa FX, Thiele-Bruhn $\mathrm{S}$, et al. Wastewater used for urban agriculture in West Africa as a reservoir for antibacterial resistance dissemination. Environ Res. 2019; 168:14-24.

30. Nordmann P, Cuzon G, Naas T. The real threat of Klebsiella pneumoniae carbapenemase-producing bacteria. Lancet Infect Dis. 2009; 9:228-236.

31. Munoz-Price LS, Poirel L, Bonomo RA, Schwaber MJ, Daikos GL, Cormican M, et al. Clinical epidemiology of the global expansion of Klebsiella pneumoniae carbapenemases. Lancet Infect Dis. 2013; 13: 785-796.
32. Cuzon G, Naas T, Truong H, Villegas MV, Wisell KT, Carmeli Y, et al. Worldwide diversity of Klebsiella pneumoniae that produce $\beta$ lactamase blaKPC-2 gene. Emerg Infect Dis. 2010; 16:1349-56.

33. Walsh TR, Toleman MA, Poirel L, Nordmannn P. Metallo- $\beta$ lactamases: the quiet before the storm? Clin Microbiol Rev. 2005; 18:306-325.

34. Nordmann P, Poirel L. Strategies for identification of carbapenemase-producing Enterobacteriaceae. J Antimicrob Chemother. 2013; 68: 487-9.

35. Struelens MJ, Monnet DL, Magiorakos AP, Santos O'Connor F, Giesecke J, European NDM-1 Survey Participants. New Delhi metallo-beta-lactamase 1-producing Enterobacteriaceae: emergence and response in Europe. Euro Surveill. 2010; 15:pii19716.

https://www.eurosurveillance.org/images/dynamic/EE/V15N 46/art19716.pdf

36. Gupta N, Limbago BM, Patel JB, Kallen AJ. Carbapenem-resistant Enterobacteriaceae: Epidemiology and prevention. Clin Infect Dis. 2011; 53:60-67.

37. Patel N, Harrington S, Dihmess A, Woo B, Masoud R, Martis P, et al. Clinical epidemiology of carbapenem-intermediate or -resistant Enterobacteriaceae. J Antimicrob Chemother. 2011; 66:1600-08.

38. Swaminathan M, Sharma S, Poliansky Blash S, Patel G, Banach DB, Phillips $M$, et al. Prevalence and risk factors for acquisition of carbapenem-resistant Enterobacteriaceae in the setting of endemicity. Infect Control Hosp Epidemiol. 2013; 34:809-817.

39. Ling ML, Tee YM, Tan SG, Amin IM, How KB, Tan KY, et al. Risk factors for acquisition of carbapenem resistant Enterobacteriaceae in an acute tertiary care hospital in Singapore. Antimicrob Resist Infect Control. 2015; 4:26.

40. Borer A, Saidel-Odes L, Riesenberg K, Eskira S, Peled N, Nativ R, et al. Attributable mortality rate for carbapenem-resistant Klebsiella pneumoniae bacteremia. Infect Control Hosp Epidemiol. 2009; 30:972-6.

41. Gasink LB, Edelstein PH, Lautenbach E, Synnestvedt M, Fishman NO. Risk factors and clinical impact of Klebsiella pneumoniae carbapenemase-producing K. pneumoniae. Infect Control Hosp Epidemiol. 2009; 30:1180-85.

42. Teo J, Cai Y, Tang S, Lee W, Tan TY, Tan TT, et al. Risk factors, molecular epidemiology and outcomes of ertapenem-resistant, carbapenem-susceptible Enterobacteriaceae: case-case-control study. PLoS One 2012; 7:e34254.

43. Bleumin D, Cohen MJ, Moranne O, Esnault VL, Benenson S, Paltiel 0 , et al. Carbapenem-resistant Klebsiella pneumoniae is associated with poor outcome in hemodialysis patients. J Infect. 2012; 65:318-25.

44. Birgy A, Doit C, Mariani-Kurkdjian P, Gene N, Faye A, Arlet G, et al. Early Detection of Colonization by VIM-1-Producing Klebsiella pneumoniae and NDM-1-Producing Escherichia coli in Two Children Returning to France. J Clin Microbiol. 2011; 49: 3085-87.

45. Overturf GD. Carbapenemases: a brief review for pediatric infectious disease specialists. Pediatr Infect Dis J. 2010; 29:6870.

46. Cavaco LM, Hansen F, Mushtaq S, Hill RLR, Woodford N, Le Hello $\mathrm{S}$, et al. Evaluation of temocillin for phenotypic carbapenemase screening of Escherichia coli and Salmonella enterica isolates in relation to the presence of genes encoding ESBLs and carbapenemase production. J Antimicrob Chemother. 2019; 74:639-644. 